\title{
Energy balance formation of sub-eutectoide fayalita at high pressures in particle separators
}

\author{
Echegaray Alberto \\ echegaray,alberto@gmail.com \\ https://orcid.org/0000-0003-4234-0452 \\ Universidad Nacional Experimental Politécnica \\ Antonio José de Sucre \\ Puerto Ordaz- Venezuela
}

Recibido (15/10/21), Aceptado (18/11/21)

\begin{abstract}
This article presents an approach to the problem of ceramic types adhesion, applying energy and matter balance to the established control volume (cyclone) with the use of mathematical formulas that are interrelated to develop mathematical calculations and establish a new mathematical model The first results are obtained by operating the energy balance considering the collision of particles, using the principle of conservation of energy, the first law of thermodynamics, in order to obtain information that allows describing the phenomena of thermoplasticity and creep, in the formation of adhesions, from a physicochemical and kinetic point of view, which will serve as the basis for understanding their effect. As a result, an energy value of $660 \mathrm{~kJ} / \mathrm{mol}$ was obtained, sufficient energy to start the transformation of the solid particles to a state of thermo-flow that allows the adhesion phenomenon to be started.
\end{abstract}

Keywords: Adhesion, energy balance, cyclones, elutriation, eutectoid, fayalite, thermoplasticity.

\section{Balance de Energía formación de fayalita Sub- eutectoide a altas presiones en separadores de partículas}

\begin{abstract}
Resumen: En este artículo se presenta una aproximación al problema de las adherencia tipos cerámicas, aplicando balance de energía y materia al volumen de control establecido (ciclón), con la utilización de fórmulas matemáticas que se interrelacionando entre sí para desarrollar los cálculos matemáticos y establecer un nuevo modelo matemático. Los primeros resultados se obtienen operando el balance energético considerando la colisión de partículas, utilizando el principio de conservación de energía, la primera ley de la termodinámica, con el fin de obtener información que permita describir los fenómenos de termo-plasticidad y fluencia, en la formación de adherencias, a partir de un punto de vista fisicoquímico y cinético, que servirá de base para comprender su efecto. Como resultado se obtuvo un valor energético de $660 \mathrm{~kJ} / \mathrm{mol}$, energía suficiente para iniciar la transformación de las partículas sólidas a un estado de termo-fluencia que permite iniciar el fenómeno de adhesión.
\end{abstract}

Palabras Clave:Adhesión, balance energético, ciclones, elutriación, eutectoide, fayalita, termoplasticidad. 


\section{I.INTRODUCCTIÓN}

Indirect reduction processes that use the fluidized bed, such as the Finmet process, which operate at pressures greater than 5 bar and temperatures greater than $600^{\circ} \mathrm{C}$, it is made up of a sequence of reactors that are inside each one of them. Four particle separators known as cyclones are located, as can be seen in figure 1 .

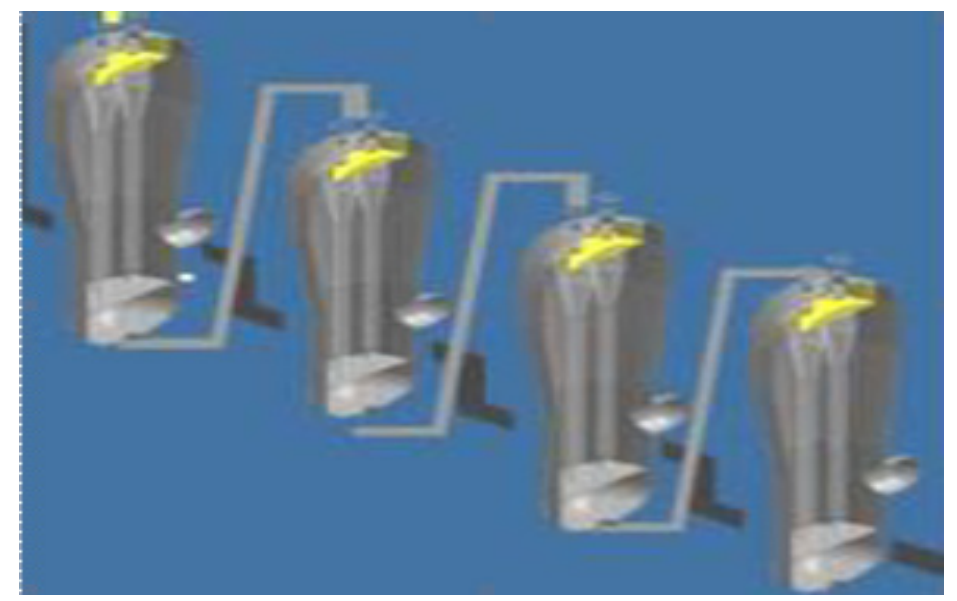

Fig 1: reactors with cyclones of the FINMET plant in Venezuela. Turmero Ruben 2010.

These cyclones for separating particles smaller than $50 \mu \mathrm{m}$ (microns), are used for their simplicity of operation and low maintenance cost due to the absence of moving parts, avoiding effects of dissipation of mechanical energy in the discharge of a hydrocyclone (Bustamante, 2013), [1] the relationship of these variables are of empirical origin and are limited to the development of correlations using experimental data, taking into consideration the design of the device considered as a "Black Box" with the use of empirical models that are still unknown. [2], [3]. These models do not consider the phenomena that occur inside the cyclone. Currently, these models are based on the physics of the fluid that has allowed them to be used in circulating fluidized bed processes (CFD), therefore a large number of numerical solutions are required that make it difficult to process the data generated inside the container. The latest approximations obtained to seek a better understanding of the separation of the size of the particles as the only consequence of the movement of the fluid, for this reason, it allows to optimize the performance and the operating conditions by examining only the flow of the gas with solid.

The literature does not report the relationships between some variables associated with the number of solids at discharge to maintain the correct operation of the equipment, without taking into account the field of internal velocity on the discharge in an incipient manner [4], [5]. From the aforementioned, it can be established that even though there is evidence of the inlet and discharge flow, it has not been included in the performance of the equipment operation. For this reason, with the aim of coupling the separation dynamics by particle size, the energetic conditions that can be used to understand these phenomena inside the cyclone separator are considered.

These considerations generate lines of research that allow giving answers to the balance of internal energies associated with the phenomenon of adhesions in the cylindrical zone of the particle separators used in circulating fluidized beds.

This article has been divided into sections, as follows: a first approach to the balance of matter to explain the phenomenon of the interaction of the particle size when it enters the cyclone separator, then a theoretical approximation of the balance of mechanical energy inside the separator is presented cyclonic starting from Cauchy's law to later finish with the validation of the calculation that allows explaining the phenomenon of adherence and operability from the energetic aspects related to the conditions of formation of the shells on the walls.

\section{ACTUAL WORK}

\section{Concept of thermal plasticity}

Few authors have introduced the concept of thermoplasticity in particle sizes that go into motion in a cyclone 
separator that is subjected to temperatures above $600^{\circ} \mathrm{C}$. However, from the perspectives of the operation of the equipment, which involves the heat generated by the impact, heat by inelastic shock, heat by chemical reactions, differentiation from significant pressures, this could be definitely decisive inefficiency.

From a thermodynamic approach, the physical meaning of the energy released by a defined particle size within the separated particle could be established. As explained in [6] that starting from Cauchy's first law and multiplying both sides by the viscosity (v).

$$
\rho \frac{D}{D_{t}}\left(\frac{v^{2}}{2}\right)=(\nabla \cdot T) \cdot v+f \cdot v
$$

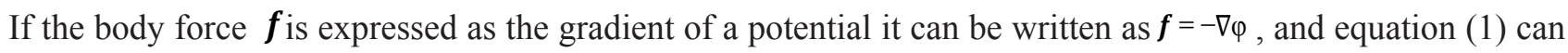
be rewritten like this:

$$
\rho \frac{D}{D_{t}}\left(\frac{v^{2}}{2}\right)=(\nabla \cdot T) \cdot v+\rho \cdot \frac{D \varphi}{D_{t}}
$$

Rearranging the terms, we finally get that:

$$
\frac{D}{D_{t}}\left(\frac{v^{2}}{2}+\varphi\right)=(\nabla \cdot T) \cdot v+T: \nabla v
$$

The product $T: \nabla v$ represents the viscous dissipation $E v$.

\section{Cyclone mass balance}

To perform the energy balance in a circulating fluidized bed reactor made up of a battery of cyclones arranged in a conical shape that internally allows the maximum separation of the solid particles found in the reducing gas stream, coming from the entrained gas bed. iron ore in wustitic thermodynamic stgte (FeO). (see figure 2) there is a schematic of the particle separator.

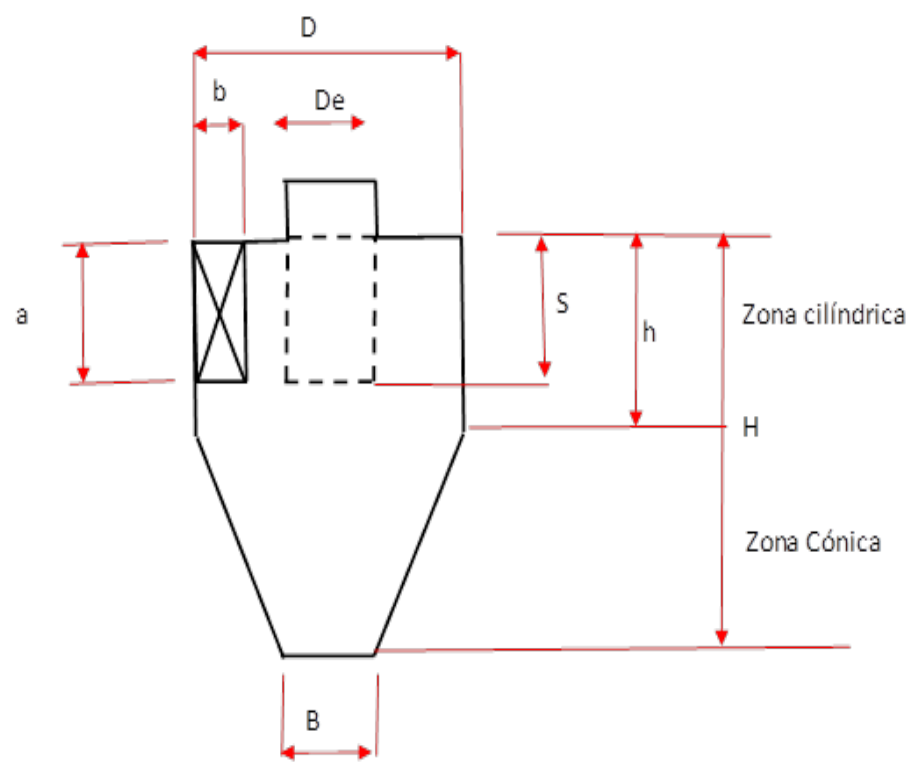

Fig 2: Schematic diagram of a particle separator (cyclone) Source: author 2020. 
Data from the cyclones used in the FINMET process plant (Venezuela). See table I where the data used for the mathematical calculations in the cyclone is shown.

Table 1

\begin{tabular}{|l|l|c|c|}
\hline Simbol & \multicolumn{1}{|c|}{ Significado } & Unidad & Valor \\
\hline $\mathrm{D}$ & Cyclone diameter & $\mathrm{mts}$ & 1,423 \\
\hline De & Cylinder diameter & $\mathrm{mts}$ & 0,508 \\
\hline$B$ & Lower outlet diameter & $\mathrm{mts}$ & - \\
\hline$H$ & Cylindrical zone height & $\mathrm{mts}$ & - \\
\hline $\mathrm{h}$ & Cylinder height & $\mathrm{mts}$ & 1,391 \\
\hline $\mathrm{S}$ & Height of outlet cylinder & $\mathrm{mts}$ & 25,57 \\
\hline $\mathrm{a}$ & Inlet height & $\mathrm{mts}$ & 0,880 \\
\hline$b$ & Inlet mouth width & $\mathrm{mts}$ & 0,278 \\
\hline
\end{tabular}

Source: Orinoco Iron cyclone plans.

For the calculations, the control volume is established, in this case the cylindrical zone of the cyclone is selected in which the mass and energy balances necessary to demonstrate its influence on the mechanism of adherence of the particles on the metallic surface of the cyclone walls, which causes the generation of shells that affect the operation of the particle separator.

Flow Characteristics

In the cylindrical zone of the cyclone a forced rotational flow is generated, causing the particles that enter the gas stream through the inlet, generating a friction force against the walls of the equipment, said inlet and outlet head loss is usually proportional to the square of the speed of the gas that circulates through the cyclone, through the Euler number $(\mathrm{Eu})$ this magnitude can be related to equation 4.

$$
E_{u}=\frac{\nabla P}{\rho_{g a s} \cdot \frac{v^{2}}{2}}
$$

Where

$\Delta \mathrm{P}$ is the pressure drop between inlet and outlet.

Pgas is the density of the gas.

$\mathrm{U}$ is the velocity of the gas as it enters.

This velocity of the gas entering the cyclone is the superficial velocity based on the internal diameter of the cyclone. (see equation 5). 


$$
U=\frac{4 * q}{\pi+D^{2}}
$$

Where

$\mathrm{q}$ is the volumetric flow rate

$\mathrm{D}$ is the internal diameter of the cylindrical zone.

The Euler number that relates pressure forces to inertial forces is practically constant for a cyclone of defined geometry.

Figure 4a describes how the particles that enter the cyclone make a circular movement towards the walls of the equipment. The net flow of the gas is radial towards the center of the tube, this force acting on the particles as described in figure $4 \mathrm{~b}$ for a given radius of the orbit of movement, these particles are dragged $(\mathrm{Fb})$, those of thrust $(\mathrm{Fu})$ and the centrifuge $(\mathrm{Fc})$, The drag forces occur towards the interior of the fluid, this is due to the fact that the gas flows into the cyclone, generating two components, the tangential velocity (Utang) and the radial velocity (Urad).

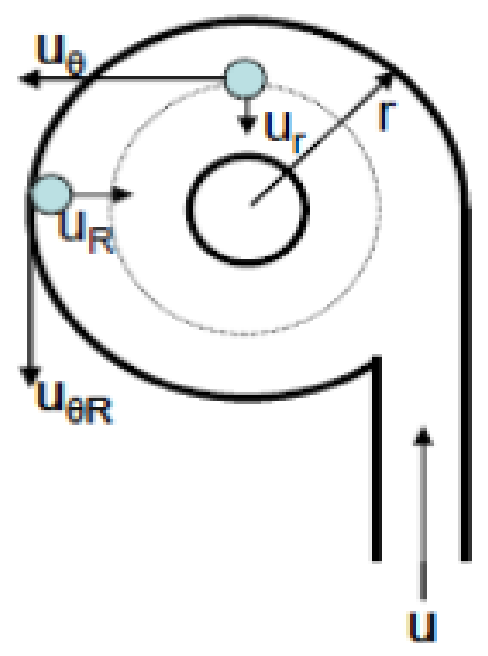

Fig 4 diagram of particle motion in a cyclone adopted by Rhodes 1998

The forces breakdown currently be considered are show in figure 4a, regarding the movement of the particles in the cylindrical zone are shown below.

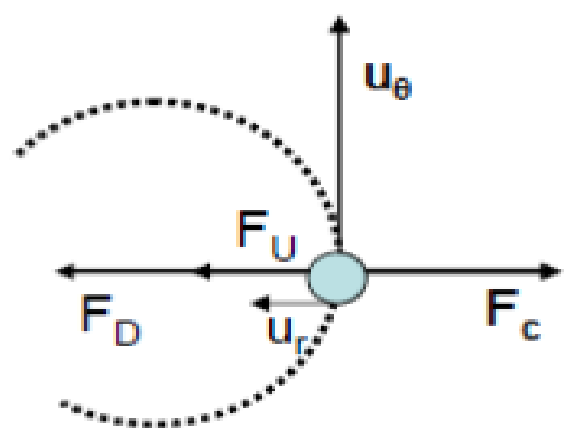

Fig $4 \mathrm{~b}$ balance of force on a particle adopted by Rhodes (1998). 
The centrifugal acceleration (ac) generated by the particle inside the cyclone when it makes a turn, is to provide the square of the tangential speed and inversely to provide the radius of the turn, see equation 6 .

$$
a_{c}=\frac{\left(U_{\operatorname{tang}}\right)^{2}}{r}
$$

Considering that $\mathrm{Fc}=\mathrm{mp}$. ac, where $\mathrm{mp}$ is the mass of the particle $\mathrm{x}$ is the diameter of the particle, it results:

$$
F_{c}=\frac{\pi * x^{3}}{6} * \rho_{p} * \frac{\left(U_{\tan g}\right)^{2}}{r}
$$

Similarly the pushing force can be written as:

$$
F_{c}=\frac{\pi * x^{3}}{6} * \rho_{g a s} * \frac{\left(U_{\text {tang }}\right)^{2}}{r}
$$

The drag force if we assume Stokes's law is valid and can be expressed as:

$$
\mathrm{F}_{\mathrm{d}}=3 * \pi * \mu * \mathrm{U}_{\mathrm{rad}} * \mathrm{r}
$$

As the particles move inward or outward until the force is swinging, at this point we can assume that the particles are in equilibrium in their orbit. In this you can verify.

$$
\begin{aligned}
& \mathrm{F}_{\mathrm{c}}=\mathrm{F}_{\mathrm{d}}+\mathrm{F}_{\mathrm{u}} \\
& \frac{\pi * x^{3}}{6} * \rho_{g a s} * \frac{\left(U_{\text {tang }}\right)^{2}}{r}=3 * \pi * \mu * U_{\text {rad }}+\frac{\pi * x^{3}}{6} * \rho_{p} * \frac{\left(U_{\text {tang }}\right)^{2}}{r} \\
& x^{2}=\frac{18 * \mu * r}{\left(\rho_{p}-\rho_{\text {gas }}\right) *\left(U_{\text {tang }}\right)^{2}} * U_{\text {rad }}
\end{aligned}
$$

Equation (12) indicates that small particles will be in equilibrium at radii close to the center of the cylinder, while the larger particles will be in equilibrium at larger radii. For this reason, the larger ones tend to be collected and the smaller ones carried away by the gas.

On the other hand, if the gas flow circulates radially as shown in figure $4 \mathrm{a}$, it results: 


$$
q=2 * \pi * r * L * U_{\text {rad }}=2 * \pi * R * L * U_{R}
$$

Where $\mathrm{q}$ is the volumetric flow rate of the gas, $\mathrm{L}$ is the height of the cylindrical section of the cyclone, $\mathrm{r}$ and $\mathrm{R}$ represent the radial coordinate evaluated at any $\mathrm{r}$ and $\mathrm{D} / 2$, while Urad and UR represent the velocity of the gas at any radius and at the area near the wall, respectively.

Substituting expressions (10) and (11) in (12) is obtained in equation 14.

$$
x^{2}=\frac{18 * \mu * r}{\left(\rho_{p}-\rho_{\text {gas }}\right)} * \frac{\left(U_{\text {tang }}\right)^{2}}{\left(U_{\text {tang }}\right)^{2} * R} *\left(\frac{r}{R}\right) U_{\text {rad }} *\left(\frac{R}{r}\right)
$$

Rearranging the terms, it is as follows:

$$
x^{2}=\frac{18 * \mu * r}{\left(\rho_{p}-\rho_{g a s}\right)} * \frac{U_{R}}{\left(U_{\text {tang }}\right)^{2}} * r
$$

Where $\mathrm{r}$ is the equilibrium orbit of the particle of size $\mathrm{x}$, in case the particles are not spherical, $\mathrm{x}$ is the $\mathrm{dv}$. If it is assumed that the particles that can be collected are those that are close to $r=R$, it results:

$$
\left(x_{\text {crit }}\right)^{2}=\frac{18 * \mu}{\left(\rho_{p}-\rho_{\text {gas }}\right)} * \frac{U_{R}}{\left(U_{\text {tang }}\right)^{2} * R} * r
$$

xcrit represents the critical size; if the particles are smaller than xcrit they will not be collected and will be carried by the gas, otherwise they will be collected at the bottom of the cyclone. If the cyclone operation complied with all the hypotheses made to conclude in equation 16 , the efficiency per class should be 0 for all particles smaller than xcrit and 1 for those with a diameter greater than xcrit .

\section{RESULTS ANALYSIS}

\section{ENERGY BALANCE IN THE CYCLONE}

The algorithm to determine the energy balance is presented in several steps as shown below, for this reason it will start with the energy balance that acts inside the particle separator where the different energies will be studied: Qimpacto; Qvacancia; Qpotential; Inelastic collision.

Identifying the input data in Table 2 to carry out the energy balance is to know how to see figure 5 where the diagram of the energy balance in the cyclone is shown table 2 . 
Table 2 variable inputs

\begin{tabular}{|l|l|l|l|}
\hline \multicolumn{1}{|c|}{ Simbol } & \multicolumn{1}{c|}{ Significado } & Unidad & Valor \\
\hline$\rho_{\text {lecho }}$ & Wustite bed density & $\mathrm{kg} / \mathrm{cm}^{3}$ & 1.543 \\
\hline$P$ & Work pressure & bar & 10 \\
\hline $\mathrm{H}_{2}$ & Hydrogen & $\%$ & 57 \\
\hline $\mathrm{CO}$ & Carbon monoxide & $\%$ & 8,95 \\
\hline $\mathrm{CO}_{2}$ & Carbon dioxide & $\%$ & 3,30 \\
\hline $\mathrm{CH}_{4}$ & Methane & $\%$ & 25,57 \\
\hline $\mathrm{N}_{2}$ & Nitrogen & $\%$ & 4,13 \\
\hline$T_{\text {entrada }}$ & Inlet temperature & ${ }^{\circ} \mathrm{C}$ & 700 \\
\hline$T_{\text {salida }}$ & Outlet temperature & ${ }^{\circ} \mathrm{C}$ & 600 \\
\hline$\rho_{\mathrm{Fe}}$ & Iron density & $\mathrm{kg} / \mathrm{m}^{3}$ & 2,461 \\
\hline & Reactor diameter & $\mathrm{mts}$ & 4,5 \\
$\varnothing$ & & & \\
\hline
\end{tabular}

Flow diagram for the energy balance in the cylindrical zone

\section{Output (2)}

$v_{x}=[\mathrm{mn} / \mathrm{s}]$

$\mathrm{P}_{\mathrm{z}}=$ [bar]

$\mathrm{A}_{\mathrm{z}}=3 / 4 \times 1-2\left(\mathrm{x}_{\mathrm{z}}-2-\mathrm{x}_{3}-2\right)$

$\mathrm{Q}_{\mathrm{z}}=[\mathrm{m} 3 \mathrm{~m} / \mathrm{s}]$

Input (1)

$\mathrm{E}_{\bar{z}}=$ [Joulle]

$\mathrm{F}=[\mathrm{gr} / \mathrm{s}]$

$V 1=[\mathrm{cm} / s]$

$P^{n}=$ [bar]

$A_{1}=3 / 4 \times 1-2$

$\mathrm{Q}_{1}=[\mathrm{m} 3 / \mathrm{s}]$

$\mathrm{E}_{1}=[\mathrm{JOU \|} \in] \mathrm{v}$

p pertibulla $[\mathrm{Kg} / \mathrm{m} 3]$

$P$ ses [kg/ $\mathrm{m} \rightrightarrows]$

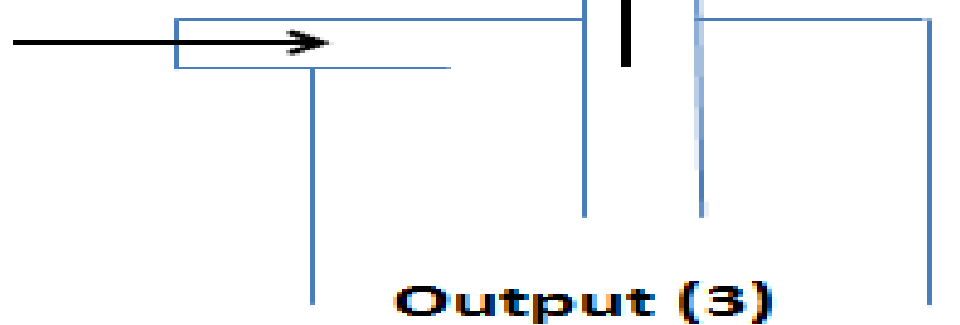

$\sum F_{3}=[\mathrm{kg} / \mathrm{s}]$

$v_{\Xi} \quad=[\mathrm{m} / \mathrm{s}]$

$P \equiv \quad=$ [bar]

$A_{\equiv} \quad=3 / 4 \times 1-2$

$Q=\quad=[\mathrm{mols}]$

$\sum E \equiv=$ [ Joulle]

$P \equiv$ Fertibulla $[\mathrm{Kg} / \mathrm{mm} \equiv]$

$\mathrm{P} \equiv \mathrm{ges}[\mathrm{kg} / \mathrm{m} \equiv]$

$\mathrm{x}_{\mathrm{E}}=[\mathrm{m}]$

Fig 5 diagram to explain the energy balance in the cyclone. Source the author 2020. 
Calculation of the molecular weight of the gas

Calculation of the molecular weight of the reducing gas $(\mathrm{Kg} / \mathrm{mol})$ Molar flow.

This is calculated by the percentage of the element times the molecular weight and divided by 100 .

$\mathrm{H} 2=57 \mathrm{gr} / \mathrm{mol} ; \mathrm{CO}=8,95 \mathrm{gr} / \mathrm{mol} ; \mathrm{CO} 2=3,30 \mathrm{gr} / \mathrm{mol} ; \mathrm{CH} 4=25,57 \mathrm{gr} / \mathrm{mol}$ and $\mathrm{N} 2=4,13 \mathrm{gr} / \mathrm{mol}$.

The molecular weight of the reducing gas is $10,37 \mathrm{gr} / \mathrm{mol}$.

\section{Calculation of the gas density using operational data}

The reducing gas density $\mathrm{kg} / \mathrm{m} 3$ is determined, applying the ideal gas law $\mathrm{P} * \mathrm{~V}=\mathrm{n} * \mathrm{R} * \mathrm{~T}$, we can substitute the number of moles that is equal to the mass over the molecular weight of the gas. Then we have the equation of the following form $\mathrm{P}^{*} \mathrm{~V}=\mathrm{m} / \mathrm{Pm} \mathrm{R}^{*} \mathrm{~T}$, now if we can clear the density of this equation, remembering that the density is equal mass over the volume, the mathematical equation is: $\mathrm{m} / \mathrm{V}=\mathrm{P} * \mathrm{PM} / \mathrm{R} * \mathrm{~T}$ we already have the formula to calculate the density, for this we have the input data.

The molecular weight of the reducing gas that was calculated in step two is $10.37 \mathrm{gr} / \mathrm{mol}$, the outlet gas temperature is $600^{\circ} \mathrm{C}$, and the working pressure is $10 \mathrm{~atm}$.

I convert 600 degrees centigrade to kelvin $=873 \mathrm{~K}$

$$
\rho=\frac{10,37 \frac{\mathrm{gr}}{\mathrm{mol}} * 10 \mathrm{~atm}}{0,0821 \frac{\text { lts*atm }}{K * m o l} * 973 \mathrm{~K}} ; \rho=0,1715 \mathrm{gr} / \mathrm{lts}=1,75 \mathrm{~kg} / \mathrm{m}^{3}
$$

\section{Calculation of bed density}

The density of the bed is calculated, for this the pressure data measured by the instrument pdi xy.18.733 is taken, which censes the density of the bed in a wustite reactor, in this case the value of 108 mbar, then it was transformed to density obtaining a value of $\rho$ of $1,542 \mathrm{~kg} / \mathrm{m} 3$.

\section{Calculation of real velocity of the gas entering the cyclone separator}

The speed of the gas that is entering each of the cyclones is determined, the inlet flow is assumed to be 200,000 $\mathrm{Nm}^{3} / \mathrm{h}$, total flow that enters the reactor, from the bottom, this flow is divided by four since it is the amount of cyclones that make up the system, in order to have a uniform distribution.

$$
Q=\frac{200.000 \frac{N m^{3}}{h}}{4} ; 50.000 \frac{\mathrm{Nm}^{3}}{h}
$$

working pressure $10 \mathrm{~atm}$ and temperature of $600^{\circ} \mathrm{C}$.

It is important to calculate the actual flow that is entering the cyclone.

Qreal is calculated with the following equation. 


$$
\begin{gathered}
Q_{\text {real }}=\frac{200.000 \frac{\mathrm{Nm}^{3}}{\mathrm{~h}}+\frac{1,013}{10 \mathrm{~atm}+1,013} *\left(273,15+600^{\circ} \mathrm{C}\right)}{273,15^{\circ} \mathrm{C}} \\
Q_{\text {real }}=58.806 \frac{\mathrm{m}^{3}}{\mathrm{~h}}
\end{gathered}
$$

Divide by 4 to determine the actual flow entering each cyclone.

$$
Q_{\text {real }}=14.701 \frac{\mathrm{m}^{3}}{\mathrm{~h}}
$$

This is actual flow that should enter the rectangular mouth of each cyclone.

\section{Calculation of the theoretical entering gas velocity}

We then proceed to calculate the velocity of the gas entering the cyclone, with the following flow equation, in which the velocity is cleared.

$\mathrm{Q}=\mathrm{V} * \mathrm{~A} ; \mathrm{V}=\mathrm{Q} / \mathrm{A}$

Where

$\mathrm{V}$ is the velocity $\mathrm{m} / \mathrm{s}$

$\mathrm{Q}$ is the flow rate $\mathrm{m} 3 / \mathrm{h}$

A is the area of the rectangular $=0,245 \mathrm{~m} 2$

The theoretical and actual speed is determined.

Theoretical V $=56,77 \mathrm{~m} / \mathrm{seg}$ (very high)

Real speed $=16,69 \mathrm{~m} / \mathrm{seg}$ (Real speed)

\section{Volume calculation of particle separation in the cylindrical zone}

The cyclone volume calculations were made to determine the mass with which the wustite mineral particles are impacting the cyclone wall.

For this reason, it is necessary to know the material of manufacture of the barrel or cylindrical area, in this case it is 304 stainless steel with the density of austenitic stainless steel AISI-304 whose density $\rho$ steel 7,980 Kg / m3 these plates have a thickness of $15 \mathrm{~mm}$, height $1,391 \mathrm{~m}$, diameter of the cyclone 1,423 $\mathrm{m}$ (D) radius $0,712 \mathrm{~m}$.

\section{Calculation of the cyclone perimeter}

$\mathrm{P}=2 * 3,1416 * 0,712 \mathrm{~m}$

$\mathrm{P}=4,470 \mathrm{mts}$

Volume calculation $\mathrm{h} * \mathrm{e} * \mathrm{P}$

$\mathrm{h}$ is the height $\mathrm{mts}$

$\mathrm{e}$ is the thickness mts 
$\mathrm{P}$ is the perimeter $\mathrm{mts}$

$\mathrm{V}=0,093 \mathrm{~m}^{3}$

\section{Calculation of inlet wall mass}

$\mathrm{M}=$ Volume $^{*}$ Steel density

$\mathrm{M}=744,53 \mathrm{~kg}$

\section{Calculation of particles impact released energy}

The impact energy is calculated with the following equation

$\mathrm{Ec}=1 / 2 \mathrm{M} * \mathrm{~V} 2$

$\mathrm{Ec}=103,707 \mathrm{~K} \mathrm{~J} / \mathrm{mol}$

\section{Calculation of energy for vacancies}

The reduction chemistry is calculated: During the transition from wustite to metallic iron, 2 vacancies are generated, with this the amount of energy associated with the reduction mechanism is determined.

\section{$2 \mathrm{FeO} \leftrightarrows \mathrm{Fe}^{+2}+2 \mathrm{O}^{-2}+2$}

$1(\square)=28 \mathrm{cal} / \mathrm{mol} ; 1 \mathrm{~J}=0,238 \mathrm{cal} / \mathrm{mol} ; 1(\square)=235,29 \mathrm{~J}$

The energy per vacancy product of the reaction of wustite with oxygen is calculated.

A vacancy is equal to $28.38 \mathrm{Kcal} / \mathrm{mol}$ Tesis Dr Oscar Dam [7].

During this process, two vacancies arise

Evac. $=4 * 28,38$ Evac. $113,20 \mathrm{Kcal} / \mathrm{mol}$

$\mathrm{Evac}=473,63 \mathrm{~K} \mathrm{~J} / \mathrm{mol}$

\section{Determination of associated chemical reactions to calculate heat capacity.}

Applying the first law of thermodynamics to explain the energy of formation of iron ferrosilicate in the proposed system.

For the formation of fayalite as expressed in the following reaction.

\section{$2\left(\mathrm{FeO} »+\iota \mathrm{SiO}_{2} \iota \leftrightarrows 2\left\langle\mathrm{FeSiO}_{4}\right\rangle\right.$}

Next, in table III, we have the elements to be used to carry out the thermodynamic calculations 
Table 3

\begin{tabular}{|c|c|c|c|}
\hline Element & $\begin{array}{c}\text { Molecular Weight } \\
(\mathrm{gr} / \mathrm{mol})\end{array}$ & $\begin{array}{c}\text { Density } \\
\left(\mathrm{gr} / \mathrm{cm}^{3}\right)\end{array}$ & $\begin{array}{c}\text { Mel ting point } \\
\left({ }^{\circ} \mathrm{C}\right)\end{array}$ \\
\hline $\mathrm{SiO}_{2}$ & 60 & 2,65 & - \\
\hline $\mathrm{FeO}$ & 72 & 5,75 & 1.377 \\
\hline $\mathrm{Fe}_{2} \mathrm{O}_{3}$ & 160 & 5,24 & - \\
\hline $\mathrm{Fe}_{3} \mathrm{O}_{4}$ & 232 & 5,17 & 1.597 \\
\hline $2 \mathrm{FeO}_{\mathrm{SiO}}$ & 203,78 & $\begin{array}{c}(3,58 \mathrm{a} \\
4,32)\end{array}$ & 1.205 \\
& & & \\
\hline
\end{tabular}

Source the author 2020

$\mathrm{CpFe}(\alpha)=37,12+6,147 \times 10-3 \mathrm{~T}-0,5 \mathrm{~J} / \mathrm{K} ; \mathrm{CpFe}(\gamma)=24,48+8,45 \times 10-3 \mathrm{~T} \mathrm{~J} / \mathrm{K}$

Thermodynamic reaction

$2 \mathrm{FeO}(s)+\mathrm{SiO}_{2}(s) \leftrightarrows 2 \mathrm{FeOSiO}_{4}(s)=\Delta \mathrm{H}^{0}{ }_{2000}=599 \mathrm{~kJ} / \mathrm{mol}$

$\mathrm{SiO} 2 \Delta \mathrm{H}^{0} 298=-910.900 \mathrm{cal} / \mathrm{mol}$

〈 $\mathrm{Si}\rangle+\left(\mathrm{O}_{2}\right) \leftrightarrows$ \ $\mathrm{Si} \mathrm{O}_{2}=\Delta \mathrm{H}^{0}{ }_{298}=-907.100+175 \mathrm{~T} \mathrm{cal} / \mathrm{mol}$

When the two reactions are combined:

$(\mathrm{Fe})+1 / 2\left(\mathrm{O}_{2}\right) \leftrightarrows(\mathrm{FeO})$

$2\langle\mathrm{FeO}\rangle+\left\langle\mathrm{SiO}_{2}\right\rangle \leftrightarrows 2\langle\mathrm{FeSiO} 4\rangle=\Delta \mathrm{H}^{0} 298=-263.700+53,68 \mathrm{~T} \mathrm{cal} / \mathrm{mol}$

Explains Eli Ringdalen, (2016) [8] Quartz $\left(\mathrm{SiO}_{2}\right)$ is the main source of silicon for the production of metallurgical grade silicon in submerged arc furnaces and with softening temperatures in the range of $1675^{\circ} \mathrm{C}$ to $1800{ }^{\circ} \mathrm{C}$, and melting temperatures in the range of $1790^{\circ} \mathrm{C}$ to $1900{ }^{\circ} \mathrm{C}$ were recorded.

$$
\mathrm{SiO}_{2}(\mathrm{~s}, \mathrm{I})+\mathrm{Si}(\mathrm{I}) \leftrightarrows 2 \mathrm{SiO}(\mathrm{g}) \Delta \mathrm{G}^{\circ} 2000 \mathrm{~K}=599 \mathrm{~kJ} / \mathrm{mol}
$$

For the formation of fayalite David R Gaskell (2003) [9] in introduction to thermodynamics so that $2 \mathrm{FeO} . \mathrm{SiO}_{2}$ is a compound formed from $\mathrm{FeO}$ with $\mathrm{SiO}_{2}$ at a pressure of 1 atmosphere, the free energy Gibbs, the following reaction is obtained.

$$
2 \mathrm{FeO}(\mathrm{s})+\mathrm{SiO}_{2}(\mathrm{~s}) \leftrightarrows 2 \mathrm{FeO} . \mathrm{SiO}_{2}(\mathrm{~s}) \mathrm{is}-11.070 \mathrm{~J}
$$

The molecular weight is $203,73 \mathrm{gr} / \mathrm{mol}$

$\Delta \mathrm{G}^{\mathrm{o}} 1200 \mathrm{~K}=54 \mathrm{KJ} / \mathrm{mol}$

Therefore, $599 \mathrm{KJ} / \mathrm{mol}$ plus $54 \mathrm{KJ} / \mathrm{mol}$ are required to start the fayalite formation process; this gives a total of $653 \mathrm{KJ} / \mathrm{mol}$.

Calculation of the heat capacity using the first law of thermodynamics

The heat of reduction reaction: It is the net heat in the passage from wustite to metallic iron, when the phase 
transformation occurs Iron( $\operatorname{Iron}(\alpha-\gamma))$ : This occurs after the impact of the particle with the metallic surface of the separator barrel mechanical cyclone, in this case the inlet gas temperature $600^{\circ} \mathrm{C}$ and outlet gas temperature $700^{\circ} \mathrm{C}$ are known, particle diameter $\varnothing$ particle $4,31 \mathrm{E}-04 \mathrm{~mm}$ and the heat capacity is calculated with the following equation. The amount of energy transferred by heat between a sample of mass $m$ of a material and its surroundings by a change in temperature from $\mathrm{T}_{1}$ to $\mathrm{T}_{2}$ is:

$$
Q=\int_{T_{1}}^{T_{2}} C_{p} * d T
$$

The energy transferred is calculated by applying the following equation $\Delta \mathrm{Q}=\mathrm{Cp} * \mathrm{~m} * \Delta \mathrm{T}$ to determine the amount of heat transferred.

Where

$\Delta \mathrm{Q}=$ Net heat transfer from gas;

Cp:=Specific heat

$\mathrm{m}=$ Mass

The amount of energy released is determined.

$\mathrm{Cp}=37,12 *(993,15 \mathrm{~K}-873,15 \mathrm{~K})+\left(6,17^{*} 10^{\wedge}-3 *\left(993,15 \mathrm{~K}^{\wedge} 2-873,15 \mathrm{~K}^{\wedge} 2\right)\right)+56,92 *\left(993,15 \mathrm{~K}^{\wedge} 0,5-873,15 \mathrm{~K}\right.$ $\wedge 0,5)+24,48^{*} 10^{\wedge} 3^{*}\left(1664^{\wedge}-3-1187^{\wedge}-3\right)$

$\mathrm{Cp}=5.948 \mathrm{~J} / \mathrm{K}$

\section{Calculation of particle volume}

Particle $=4 / 3 *(1) * 3,1416$

Varticle $=4,188 \mathrm{~cm} 3$

Mass $=$ Density $*$ Vparticle

Mass $=4,32 \mathrm{gr} / \mathrm{cm} 3 * 4.188 \mathrm{~cm} 3$

Mass $=18,096 \mathrm{gr}=0.018096 \mathrm{~kg}$

The density of $\mathrm{FeO} 5,77 \mathrm{gr} / \mathrm{cm} 3$ and the density of $\mathrm{SiO} 22,62 \mathrm{gr} / \mathrm{cm} 3$ are known

Inlet temperature $600^{\circ} \mathrm{C}$ outlet temperature $700^{\circ} \mathrm{C}$

The temperature in Kelvin $273,15+{ }^{\circ} \mathrm{C}$

Tempted $=873,15 \mathrm{~K}$

Tsalida $=973,15 \mathrm{~K}$

$\mathrm{Q}=\mathrm{m} * \mathrm{Cp} * \Delta \mathrm{T}$

$\mathrm{Q}=12,92 \mathrm{KJ} / \mathrm{mol}$

Creep temperature when working with $600{ }^{\circ} \mathrm{C}$,

$\mathrm{TC}=873 / 1808=0,478$

$\mathrm{Tc}=0,478 * \mathrm{Tf}$

Where

Tc is the critical temperature; Tf is the melting temperature of iron.

\section{RESULTS}

To carry out the energy balance, the composition of the gas that enters the wustite reactor with the following molecular weight $10,37 \mathrm{~g} / \mathrm{mol}$ and working temperature of $600^{\circ} \mathrm{C}$ to $800^{\circ} \mathrm{C}$ with working pressures of 10 bar was taken.

Next, table 4 of the results of the energy balance that acts in the internal part of the cyclone separator is shown, in order to explain the adhesion formations and therefore the generation of the fayalite is possible. 
Table 4

\begin{tabular}{|l|c|c|}
\hline \multicolumn{1}{|c|}{ MEANING } & $\begin{array}{c}\text { UNIT } \\
\text { (KJ/MOL) }\end{array}$ & $\begin{array}{c}\text { UNIDAD } \\
\text { (KCAL/MOL) }\end{array}$ \\
\hline Energy per impact & 103,71 & 29,79 \\
\hline Energy per vacancy & 473,63 & 113,20 \\
\hline Energy per particle collision & 12,92 & 3,09 \\
\hline Energy due to inelastic collision & 69,75 & 16,67 \\
\hline Total Energy & 660,01 & 157,74 \\
\hline
\end{tabular}

Source: the author 2020

\section{V.CONCLUSIONS}

For the fusion of quartz in a liquid state at $2,000 \mathrm{~K}, 599 \mathrm{KJ} / \mathrm{mol}$ is required and for the fusion of fayalite at $1200 \mathrm{~K}, 54 \mathrm{KJ} / \mathrm{mol}$ is required, the sum of energy gives a total of $653 \mathrm{KJ} / \mathrm{mol}$ with this amount of energy being is guaranteeing the formation of this ferrosilicate, by energy balance it was determined that $660 \mathrm{KJ} / \mathrm{mol} \mathrm{enough}$ energy is generated to guarantee the softening point of the particles inside the cyclone separator.

The formation of adhesions in the form of shells in the cylindrical zone in the temperature range greater than $600^{\circ} \mathrm{C}$ and pressures greater than $10 \mathrm{bar}$, is possible in fluidized bed processes when they work with molecular weights in the gas of $10 \mathrm{gr} / \mathrm{mol}$.

Thermoplasticity in the studied temperature range $600^{\circ} \mathrm{C}(873 \mathrm{~K})$ to reach the melting point of iron requires the following factor 0.478 , obtaining the following equation $\mathrm{Tc}=0.478 * \mathrm{Tf}$.

The results shown in the summary table of the summation of the energies released inside the cyclone separator is $660 \mathrm{KJ} / \mathrm{mol}$ higher than the $599 \mathrm{KJ} / \mathrm{mol}$ that is required to melt the silicon oxide at $2000^{\circ} \mathrm{C}$.

\section{RECOGNITION}

The authors are especially grateful to the Directorate of Postgraduate Research at UNEXPO for the opportunity to write a research article related to the energy balance to explain the formation of fayalite inside the cyclonic separator that occurs at temperatures below the point eutectic.

\section{REFERENCES}

[1]O. Bustamante. "Dissipation of mechanical energy in the discharge of a hydrocyclone". (Dyna, Ed.) The network of Scientific Journals of Latin America, the Caribbean, Spain, and Portugal, vol. 80 (181), Pages 136143,2013

[2]K.Petersen, P.Aldrich, and D.Van.,"Hydrocyclone underflow monitoring using image processing methods. Minerals Engineering", pp. 301-315,1996

[3]M. Farghaly," Controlled Wash Water Injection to the hydrocyclone underflow" [Ph.D. Thesis]. Erlangen, FAU,2009

[4]M, Schneider, and T. Neesse. "Overflow-control system for a hydrocyclone battery. Int. J. Miner. Process". 74, pp. $339-343,2004$.

[5]J.Bergström., "Flow field and fiber fractionation studies in hydro cyclones" [Ph.D. Thesis] Stockholm, Sweden, Royal Institute of Technology,2006

[6]C, Liu, L. Wang, and Q. Lui., "Investigation of energy loss mechanisms in cyclone separators". Chemical Engineering Technology 28, pp. 1182-1190,2005

[7]O.Dam. \& E.Jeffes.,."'Model for detailed assessment of chemical composition of reduced iron ores from single measurement". Ironmaking and Steelmaking, 1987

[8]E. Ringdalen., "Softening and melting of $\mathrm{SiO} 2$ an important parameter for reactions with quartz in Si production" pp 43-44,2016 
[9]R. Gaskell., "Introduction to the Thermodynamics of Materials. New York: Taylor \& Francis" pp 614-616,2003

\section{CURRICULUM SUMMARY}

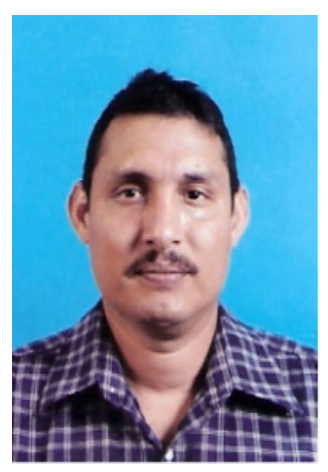

Alberto R Echegaray R, Metallurgical Engineer Graduated from Unexpo Puerto Ordaz de Venezuela in 2002. Master Sinence in Metallurgy and Postgraduate in simulation, Energy Efficiency, Specialist in Maintenance Management. Studying a $\mathrm{PhD}$ in Engineering Science at Unexpo. Member of the engineering college. I have worked since (1998) in Fior de Venezuela in (2000) I move to the start-up group of Finmet Technology in Orinoco Iron (Orinoco Briquetera) with the position of operation technician, technical assistant and later as Specialist of level IV process. I am currently working in the Energy Management department attached to the Presidency. 